Jurnal Belantara [JBL] Vol. 1, No. 2, Agustus 2018 (101-106)

E-ISSN 2614-3453

DOI: https://doi.org/10.29303/ibl.v1i2.83

P-ISSN 2614-7238

\title{
SIFAT FISIKA BAMBU PETUNG (Dendrocalamus asper (Schult. f.) Backer ex Heyne) dari KHDTK (Kawasan Hutan Dengan Tujuan Khusus) SENARU BERDASARKAN POSISI AKSIAL
}

\author{
Physical Properties of Bamboo Petung (Dendrocalamus asper (Schult. f.) Backer ex Heyne) \\ from KHDTK Senaru Based on Axial Position. \\ Dwi Sukma Rini \\ Program Studi Kehutanan, Universitas Mataram \\ JI.Majapahit No. 62, Mataram, NTB \\ Email: dwisukmarini@unram.ac.id
}

\begin{abstract}
The aims of this study are to determine the influence of bamboo culm section, axial position, and interaction between the culm section and the axial position on physical properties of bamboo petung derived from KHDTK SENARU, North Lombok. The method used in this study was the experimental method using a completely randomized factorial design (CRFD) with two factor. The first factor was the culm section (node and internode) and the second factor was the axial position (bottom, middle and top). Parameters that were observed in this study were green moisture content (MC), air dried MC, green specific gravity, longitudinal and thick shrinkage from green condition to oven dried condition. Data analysis used is the analysis of variance with a confidence level of 95\%. The result shows that culm section, the interaction between culm section and axial position did not give significant influence on physical properties. While the axial position which included green MC and green specific gravity has a significant influence on physical properties. A further test was done on a significant result using Tukey's HSD test. Green MC decreases along the culm from base to top. In contrast, green specific gravity increases along the culm from base to top.
\end{abstract}

Keywords: axial; bamboo; petung; physical; properties

\begin{abstract}
Abstrak
Tujuan penelitian ini adalah untuk mengetahui pengaruh bagian batang bambu, posisi aksial batang, dan interaksi keduanya terhadap sifat fisika bambu petung yang berasal dari Kawasan Hutan Dengan Tujuan Khusus (KHDTK) Senaru, Lombok Tengah. Metode yang digunakan adalah metode eksperimen dengan Rancangan Acak Lengkap (RAL) Faktorial. Faktor pertama adalah arah aksial batang (pangkal, tengah dan ujung) dan faktor kedua adalah bagian batang (ruas dan buku). Parameter yang diamati dalam penelitian ini meliputi kadar air segar, kadar air kering udara, berat jenis segar, penyusutan longitudinal dan penyusutan tebal pada kondisi segar ke kering tanur. Analisis data dilakukan dengan menggunakan analisis sidik ragam pada taraf nyata $5 \%$. Hasil penelitian menunjukkan bahwa bagian batang (ruas dan buku), interaksi antara arah aksial dan bagian batang tidak berpengaruh terhadap sifat fisika bambu petung, sementara faktor arah aksial berpengaruh nyata terhadap parameter kadar air segar dan berat jenis segar bambu petung. Hasil Uji
\end{abstract}


lanjut Tukeys HSD menunjukkan bahwa bagian pangkal, tengah, dan ujung memiliki nilai kadar air segar dan berat jenis segar yang berbeda nyata. Kadar air segar semakin menurun menuju bagian ujung, sementara berat jenis mengalami peningkatan dari bagian pangkal menuju bagian ujung.

Kata kunci: aksial, bambu, petung, fisika, sifat

\section{Pendahuluan}

Tanaman bambu merupakan jenis tanaman yang banyak dibudi dayakan dan dimanfaatkan oleh masyarakat Indonesia. Tanaman bambu hidup berumpun dan tersebar luas di seluruh wilayah Indonesia, biasanya ditemukan di daerah pinggir sungai atau tegalan. Bambu telah dikenal dan banyak digunakan baik secara tradisional maupun komersial sebagai bahan baku mebel dan konstruksi pengganti kayu. Maraknya isu lingkungan dengan semboyan kembali ke alam membuat bambu kembali dilirik sebagai salah satu bahan bangunan yang memiliki sifat-sifat yang lebih baik dari kayu.

Keunggulan bambu dibandingkan dengan kayu yaitu dapat tumbuh lebih cepat sehingga bisa dipanen dalam waktu singkat, tahan terhadap kekuatan beban yang tinggi, serta mampu mengurangi polusi lingkungan karena menyerap nitrogen dan karbon dioksida $(\mathrm{CO})_{2}$ dalam jumlah yang tinggi (Leelatanon, Srivaso, \& Matan, 2010). Dilihat dari penampilannya bambu memiliki nilai estetika dengan pembawaan alami, halus dan warna yang indah tanpa perlu dicat. Bambu yang ditebang cukup umur memiliki bentuk batang yang lurus dan mudah dikemas. Selain itu bambu memiliki harga yang relatif murah dibanding bahan bangunan lain karena tumbuh di banyak tempat dan produksi per tahunnya cukup melimpah, tidak polutan, ramah lingkungan dan bisa tumbuh dengan sedikit air.

Jenis bambu yang banyak dimanfaatkan salah satunya adalah bambu petung (Dendrocalamus asper (Schult.F.) Backer ex Heyne). Bambu petung memiliki ukuran batang yang jauh lebih besar dari jenis lainnya dengan ruas yang lebih pendek. Bambu petung biasa dimanfaatkan rebungnya sebagai bahan makanan sementara batang bambu petung banyak digunakan untuk bahan konstruksi karena ukuran batang yang besar dan memiliki dinding yang tebal. Batang bambu petung juga dihargai lebih tinggi dari jenis bambu lain.

Pemanfaatan bambu petung sebagai bahan konstruksi pengganti kayu perlu didukung dengan informasi terkait sifat fisika seperti kadar air, berat jenis, dan penyusutan. Ditambah lagi batang bambu terdiri dari bagian ruas dan buku yang memiliki struktur yang berbeda dan diduga akan berpengaruh terhadap sifat dari setiap bagian tersebut. Oleh karena itu penelitian ini bertujuan untuk menganalisis pengaruh bagian batang bambu, yaitu bagian ruas dan buku yang terdapat di sepanjang arah aksial batang terhadap sifat fisika bambu petung.

\section{Metode}

Penelitian ini dilakukan pada bambu petung yang berasal dari Kawasan Hutan Dengan Tujuan Khusus (KHDTK) Senaru, Lombok Tengah. Pengujian dilakukan di Laboratorium Silvikultur dan Teknologi Hasil Hutan, Program Studi Kehutanan, Universitas Mataram pada bulan Oktober-Desember 2017. Metode yang digunakan adalah metode eksperimen dengan Rancangan Acak Lengkap (RAL) Faktorial. Faktor pertama adalah posisi aksial batang, terdiri dari tiga aras, yaitu Pangkal (P), Tengah (T) dan Ujung (U). Faktor kedua adalah bagian batang, terdiri dari dua aras, yaitu bagian buku (N) dan bagian ruas (I). Jumlah ulangan untuk setiap pengujian adalah 3 kali. 
Sifat fisika yang diuji meliputi kadar air, berat jenis, dan perubahan dimensi pada arah tebal dan lebar, mengacu pada standar India (IS 6874, 2008). Ukuran contoh uji untuk kadar air dan berat jenis adalah 2,5 cm (panjang) x 2,5 cm (lebar), sedangkan tebalnya mengikuti tebal bambu. Panjang contoh uji untuk penyusutan bambu adalah $10 \mathrm{~cm}$ dan bebas dari buku.

Contoh uji kadar air ditimbang pada kondisi segar, kemudian dikeringkan dalam oven dengan suhu $103 \pm 2^{\circ} \mathrm{C}$ selama 24 jam, berat contoh uji ditimbang setiap 2 jam hingga beratnya konstan (perbedaan berat tidak lebih dari 0,01 g). Kadar air tiap contoh uji dihitung dengan rumus :

$$
\text { Kadar air }(\%)=\frac{m i-m o}{m o} \times 100 \%
$$

Keterangan:

$m i=$ berat awal contoh uji $(\mathrm{g})$

$m o=$ berat kering tanur $(\mathrm{g})$

Pengujian berat jenis dilakukan dengan menimbang berat awal contoh uji dengan ketelitian 0,01 g. Kemudian volume segar diukur dengan metode pencelupan.Contoh uji yang telah diukur volume di kering tanurkan. Berat jenis dihitung dengan rumus:

$$
\text { Berat jenis }=\frac{m o}{V g}
$$

Keterangan :

$m o=$ berat kering tanur $(\mathrm{g})$

$V g=$ volume segar $\left(\mathrm{cm}^{3}\right)$

Pengujian penyusutan bambu dilakukan dengan mengukur tebal dinding dan panjang contoh uji. Pengukuran dilakukan pada area yang telah ditandai dan diukur berulang-ulang sampai kondisi kering udara. Setelah itu contoh uji dikeringkan dalam oven hingga kering tanur, kemudian dimensi kering tanur diukur pada area yang telah ditandai. Persentase penyusutan dihitung sebagai berikut:

$$
\begin{gathered}
\text { Penyusutan tebal (\%) }=\frac{t i-\mathrm{tf}}{t i} \times 100 \% \\
\text { Penyusutan panjang(\%) }=\frac{l i-\mathrm{lf}}{l i} \times 100 \%
\end{gathered}
$$

Ket :

$t i, l i=$ dimensi awal $(\mathrm{cm})$

tf, If = dimensi akhir $(\mathrm{cm})$

\section{Hasil Dan Pembahasan}

Sifat fisika yang dianalisis pada bambu petung yang berasal dari KHDTK Senaru meliputi kadar air segar, kadar air kering udara, berat jenis segar, penyusutan longitudinal dari kondisi segar ke kondisi kering tanur dan penyusutan tebal dari kondisi segar ke kondisi kering tanur di sepanjang arah aksial pada bagian ruas dan buku. 


\section{Kadar Air}

Rata-rata nilai kadar air segar bambu petung yang berasal dari KHDTK Senaru adalah $52,67 \%$. Nilai kadar air ini termasuk rendah jika dibandingkan dengan rata-rata kadar air segar bambu jenis lain. Sebaran nilai kadar air disepanjang batang dapat dilihat pada Tabel 1.

Tabel 1. Rata-rata kadar air segar bambu petung KHDTK Senaru (\%)

Table 1. Mean green moisture content of bamboo petung from KHDTK Senaru (\%)

\begin{tabular}{lccc}
\hline \multirow{2}{*}{ Aksial } & \multicolumn{2}{c}{ Bagian } & \multirow{2}{*}{ Rata-rata } \\
\cline { 2 - 3 } & Ruas & Buku & \\
\hline Pangkal & 60,97 & 57,38 & 59,18 \\
Tengah & 50,72 & 52,21 & 51,47 \\
Ujung & 46,78 & 47,94 & 47,36 \\
\hline Rata-rata & 52,82 & 52,51 & 52,67 \\
\hline
\end{tabular}

Berdasarkan Tabel 1. Diketahui bahwa kadar air segar bambu petung memiliki nilai yang cenderung menurun dari bagian pangkal menuju bagian ujung. Hal ini dikarenakan pada bagian pangkal bambu memiliki dinding serabut yang lebih tebal daripada bagian ujung sehingga kemampuan mengikat air lebih besar. Kecenderungan kadar air bambu menurun dari pangkal ke batang atas ini juga karena sel parenkim yang merupakan tempat penampungan air semakin ke atas semakin berkurang persentasenya (Fangchun, 2000; Nahar \& Hasan, 2013). Hasil analisis keragaman menunjukkan bahwa posisi aksial bambu berpengaruh nyata terhadap nilai kadar air segar, dimana kadar air bagian pangkal berbeda nyata dengan bagian tengah dan juga berbeda dengan bagian ujung, sedangkan keberadaan buku dan ruas tidak berpengaruh terhadap nilai kadar air segar.

Sementara itu, nilai kadar air kering udara bambu petung yang berasal dari KHDTK Senaru relatif seragam. Rata-rata nilai kadar air kering udara yaitu $11,08 \%$. Hasi uji statistika menunjukkan bahwa tidak ada perbedaan kadar air kering udara pada arah aksial, baik pada bagian buku maupun ruas.

Tabel 2. Rata-rata kadar air kering udara bambu petung KHDTK Senaru (\%)

Table 2. Mean air dried moisture content of bamboo petung from KHDTK Senaru (\%)

\begin{tabular}{cccc}
\hline \multirow{2}{*}{ Aksial } & \multicolumn{2}{c}{ Bagian } & \multirow{2}{*}{ Rata-rata } \\
\cline { 2 - 3 } & Ruas & Buku & \\
\hline Pangkal & 11.03 & 11.25 & 11.14 \\
Tengah & 10.85 & 11.33 & 11.09 \\
Ujung & 10.76 & 11.26 & 11.01 \\
\hline Rata-rata & 10.88 & 11.28 & 11.08 \\
\hline
\end{tabular}

\section{Berat Jenis}

Nilai berat jenis bambu petung terlihat seragam (Tabel.3) yaitu berkisar antara 0,430,62 . Pada arah aksial berat jenis memiliki pola meningkat dari pangkal ke ujung. Hal ini berlaku sama pada bagian buku dan ruas, dimana baik bagian buku dan ruas memiliki kecenderungan pola yang sama pada arah aksial. Sementara untuk bagian bambu buku memiliki nilai berat jenis yang lebih tinggi daripada bagian ruas. 
Tabel. 3 Nilai Rata-rata Berat Jenis Segar Bambu Petung

Table 3. Mean green specific grafity bamboo petung from KHDTK Senaru (\%)

\begin{tabular}{cccc}
\hline \multirow{2}{*}{ Aksial } & \multicolumn{2}{c}{ Bagian } & \multirow{2}{*}{ Rata-rata } \\
\cline { 2 - 3 } & Ruas & Buku & 0.460 \\
Pangkal & 0.43 & 0.48 & 0.559 \\
Tengah & 0.57 & 0.55 & 0.614 \\
Ujung & 0.62 & 0.61 & 0.544 \\
\hline Rata-rata & 0.539 & 0.549 & \\
\hline
\end{tabular}

Hasil uji statistik pada taraf nyata $5 \%$ menunjukkan bahwa arah aksial berpengaruh nyata terhadap berat jenis segar, sementara bagian batang dan interaksi arah aksial dan bagian batang tidak berpengaruh nyata. Berdasarkan uji lanjut HSD, diketahui bahwa bagian pangkal berbeda dengan bagian tengah dan ujung, dan bagian tengah berbeda dengan bagian ujung. Berat jenis pada arah aksial berbeda disebabkan oleh ikatan yang tersusun dalam bambu meningkat dari bagian bawah menuju ke bagian atas, sehingga persentase sel serabut juga bertambah besar di bagian ujung. Hal ini menyebabkan volume total zat dinding sel akan meningkat. Selain itu perbedaan berat jenis juga dapat disebabkan meningkatnya kandungan silica dari bagian pangkal ke bagian ujung, sehingga berat jenis bagian ujung cenderung lebih tinggi (Epsiloy, 1987). Dijelaskan dalam Daza dan Arbeláez (2010) bahwa kenaikan kerapatan bambu dari batang pangkal ke batang atas terjadi karena porsi jaringan sklerenkim semakin ke atas batang cenderung semakin banyak jumlahnya. Jaringan sklerenkim adalah jaringan yang dibangun dari serat mikro selulosa dalam matriks hemiselulosa dan lignin yang berfungsi memberikan kekuatan, fleksibilitas, dan kekakuan pada tanaman (Jarvis, 2012). Meningkatnya kerapatan batang dapat dijadikan sebagai salah satu indikator meningkatnya kekuatan bambu.

\section{Penyusutan}

Nilai rata-rata penyusutan bambu petung yang berasal dari KHDTK Senaru dari kondisi segar ke kering tanur disajikan pada Tabel 4. Rata-rata penyusutan pada arah longitudinal yaitu $0,4 \%$, sementara nilai penyusutan tebalnya sangat tinggi yaitu12,22\%. Penyusutan bambu dalam penelitian ini diukur pada bagian ruas bambu. Hasil penelitian menunjukkan bahwa pada arah longitudinal bambu memiliki nilai penyusutan tinggi di bagian pangkal, menurun dibagian tengah dan sedikit meningkat di bagian ujung. Sementara pada penyusutan tebal, bagian pangkal memiliki angka penyusutan tebal terendah lalu meningkat ke bagian tengah dan turun kembali ke bagian ujung batang. Berdasarkan hasil analisis keragaman menunjukkan bahwa posisi aksial batang bambu tidak berpengaruh terhadap penyusutan bambu dari kondisi segar ke kondisi kering tanur,baik untuk penyusutan longitudianal maupun peyusutan tebal. Ini menunjukkan bahwa walaupun terjadi perbedaan nilai penyusutan pada arah aksial tetapi masih dianggap tidak berpengaruh.

Tabel 4. Nilai Rata-rata Penyusutan Segar-Kering Tanur 
Table 4. Mean shrinkage from green to air dried condition of bamboo petung from KHDTK Senaru (\%)

\begin{tabular}{ccc}
\hline \multirow{2}{*}{ Aksial } & \multicolumn{2}{c}{ Penyusutan $(\%)$} \\
\cline { 2 - 3 } & Longitudinal & Tebal \\
\hline Pangkal & 0,64 & 12,27 \\
Tengah & 0,24 & 18,83 \\
Ujung & 0,32 & 14,56 \\
\hline Rata-rata & 0,40 & 15,22 \\
\hline
\end{tabular}

\section{Kesimpulan}

Berdasarkan hasil analisis data, dapat ditarik kesimpulan sebagai berikut:

1. Bagian batang bambu (ruas dan buku) tidak memberikan pengaruh terhadap sifat fisika bambu petung yang berasal dari KHDTK Senaru

2. Posisi aksial bambu berpengaruh nyata terhadap sifat fisika bambu petung yang berasal dari KHDTK Senaru, yaitu kadar air segar dan berat jenis segar

3. Interaksi antara bagian batang dan posisi aksial bambu tidak berpengaruh terhadap sifat fisika bambu petung yang berasal dari KHDTK Senaru.

\section{Daftar Pustaka}

Daza, J.F.C., \& Arbeláez, J. (2010). Influence of age and height position on Colombian Guadua angustifolia bamboo mechanical properties. Maderas Ciencia Tecnología, 12(2), 105-113 doi: 10.4067/S0718-21X2010000200005.

Espiloy, Z.B. 1987. Physico-mechanical properties and anatomical relationship of some Philippine bamboos.In Rao, A.N.; Dhanarajan, G.; Sastry, C.B. ed., Recent Research on Bamboo. Proceedings of the International Bamboo Workshop, Hangzhou, China, 614 October 1985. Chinese Academy of Forestry, Beijing, China; International Development Research Centre, Ottawa, Canada. pp. 257-264

Fangchun, Z. (2000). Selected works of bamboo research. The Bamboo Research Editorial Committee Chapter XII-XIV (pp. 95-125). China: Nanjing Forestry University

Indian Standard (IS). (2008). Method of tests for bamboo. Timber and Timber Stores (IS 6874-2008), First Revision. New Delhi: Bureau of Indian Standards.

Jarvis, M.C. (2012). Sclerenchyma Encyclopedia of life sciences. Published Online: 15 Aug 2012, doi: 10.1002/9780470015902. a0002082.pub2. Glasbow University, Glasgow Scontland. Chichester, UK: John Willey \& Sons Ltd. Diakses dari http://www/els.net.

Leelatanon, S., Srivaro, S., \& Matan, N. (2010).Compressive strength and ductility of short concrete columns reinforced by bamboo. Songklanakarin Journal of Science and Technology, 32(4), 419-424.

Nahar, S., \& Hasan, M. (2013).Effect of chemical composition, anatomy and cell wall structure on tensile properties of bamboo fiber.Engineering Journal, 17(1), 61-68 doi: 10.4186/ej.2013.17.1.61. 